\title{
LABOR COURTS, NOMINATION BIAS, AND UNEMPLOYMENT IN GERMANY
}

\author{
HELGE BERGER \\ MichAEL NeUGART
}

CESIFO WORKING PAPER NO. 1752

CATEGORY 4: LABOUR MARKETS

JUNE 2006

\footnotetext{
An electronic version of the paper may be downloaded

- from the SSRN website:

www.SSRN.com

- from the RePEc website:

Www.RePEc.org

- from the CESifo website:

www.CESifo-group.de
} 


\title{
LABOR COURTS, NOMINATION BIAS, AND UNEMPLOYMENT IN GERMANY
}

\begin{abstract}
Labor courts play an important role in determining the effective level of labor market regulation in Germany, but their application of law may not be even-handed. Based on a simple theoretical model and a new panel data set, we identify a nomination bias in labor court activity - that is, court activity varies systematically with the political leaning of the government that has appointed judges. In an extension, we find a significant positive relation between labor court activity and unemployment, even after controlling for the endogeneity of court activity. The results have potentially important policy implications regarding the independence of the judiciary and labor market reforms.
\end{abstract}

JEL Code: J53, K31, K41, E24.

Keywords: courts, labor courts, law production, nomination bias, unemployment, regulation, firing costs, Germany.

Helge Berger

Free University Berlin

Economics Department

Boltzmannstr. 20

14195 Berlin

Germany

hberger@wiwiss.fu-berlin.de
Michael Neugart

WZB (Social Science Research Center)

Labor Market Policy and Employment

Reichpietschufer 50

10785 Berlin

Germany

neugart@wz-berlin.de

June 2006

We thank, among others, Stephan Danninger, Laszlo Goerke, Markus Pannenberg, Claus Scholl, Klaus Sturm, Georg von Wangenheim, and Holger Wolf for helpful comments and suggestions. Steffen Dähne, Anne-Kristin Koch, and Jörg Reddig provided able research assistance. 


\section{Introduction}

The activity of German labor courts is interesting from a number of perspectives. ${ }^{1}$ From a normative point of view, most people would probably agree on the principle that the application of law should be independent from the specific judge or the appointing authority. The question of a possible nomination (or ideological) bias in the appointment process of judges - that is, a preference for nominating judges with political leanings close to the incumbent government - seems to be most relevant in court or case-law-based legal systems, a point underscored by the recurring battle over Supreme Court nominations in the Unites States. However, the issue is also of considerable importance in German labor law. Labor law is the one domain in the German legal system where the interplay of lower-level and higher-level courts is more or less unrestrained by lawmakers. ${ }^{2}$ As a consequence, judges enjoy (at least by German standards) an unusually high degree of independence in setting and implementing labor law and standards, leading to some degree of unpredictability even for legal experts (Sachverständigenrat (2003)). ${ }^{3}$ In particular, judges have an important influence on the discretion of firms to adjust their workforce through dismissals and on wage issues. ${ }^{4}$

The high unemployment rate also makes German labor court activity an object of interest to economists. The OECD (2004b) identifies labor courts as an important factor in the implementation of labor market regulation in general, and employment protection in particular - an area that many economist hold at least partially responsible for weak employment growth in Germany and elsewhere in Europe. ${ }^{5}$ The literature also suggests that court

\footnotetext{
${ }^{1}$ Throughout the text, we use the terms court activity or court production to summarize the full range of court actions, including the number of cases filed with courts, settlements, decisions, and appeals.

${ }^{2}$ For instance, the Kündigungsschutzgesetz of 1951, the German Protection Against Dismissal Law relevant for the majority of cases brought in front of labor courts, places few restrictions on court behavior. In principle, courts ask on a case-by-case basis whether dismissals were the "ultima ratio", based on an "important" reason or "socially justified", with the burden-of-proof placed on employers. Since most of these tests and terms are a matter of interpretation, the labor courts de facto determine the actual size of firing costs (see Richardi and Wlotzke (1992)).

${ }^{3}$ As we will argue below, an important part of the uncertainty may be changes in the composition of labor courts through the nomination process.

${ }^{4}$ Contract disputes over dismissals and, to a somewhat smaller degree, wage issues are behind the vast majority of cases filed with German labor courts. During the period 19702004, about 44 percent of all case filed concerned dismissals (approaching 50 percent in more recent years) and about 39 percent wage disputes. See Appendix 2.

${ }^{5}$ See, inter alia, (Young (2003), OECD (2004a), OECD (2004b), and Berger and Danninger (2006)).
} 
activity may matter even if only some cases are actually heard simply because of the possibility of employees appealing to labor courts (OECD (2004b)).

As to the German case, there is some evidence that labor courts may indeed play an important and not necessarily positive role in the dismal performance of the German labor market since the 1970s. For instance, based mostly on anecdotal evidence, Soltwedel (1983) and Franz (1994) assert that a new generation of judges appointed to labor courts at all levels starting in the late 1960s moved systematically to strengthen the contractual position of workers, including by making it significantly more difficult for firms to reduce their workforce. This, in turn, sharply raised labor and firing costs, with negative repercussions for employment. ${ }^{6}$

We extend the existing literature in a number of directions. First, we develop a simple model describing the behavior of employees and firms before and during labor court procedures at the lower and the higher level, yielding a number of testable hypotheses that can be used to identify the repercussions of a nomination bias in court activity. The model's key mechanism is the way nomination bias interferes with the trade-offs faced by forwardlooking workers and firms along the different stages of the legal process. For instance, before allowing a case to go to the lower-level court, both sides will compare the safe payoff of a pre-court settlement with the uncertain outcome of the legal procedure. If there is nomination bias at the higher labor court level, then a change in the direction of the bias will influence the expected payoffs stemming from their interaction. ${ }^{7}$ This will affect the behavior of firms and workers who compare the benefit from filing a claim with those a settlement would yield. Thus, empirically one should be able to trace an effect of nomination bias in the number of filed claims. Working through the same channel, changes in the direction of nomination bias will, in addition, influence the willingness of workers and firms to accept a lower-level court settlement, the share of lower-level court decisions that is appealed, and the willingness of firms and workers to settle their case at the higher-level court.

To take these hypotheses to the data, we construct a new panel data set including information on lower- and higher-level labor court activity (i.e., decisions, settlements, and appeals), higher-level labor courts characteristics, the ideology of the state ( Länder) governments nominating higher-level court judges, and relevant economic data for the German states starting in the 1970s (for the West German states) until 2004. The empirical analysis uses

\footnotetext{
${ }^{6}$ This view has received some support from a macro perspective (Berger (1998)).

${ }^{7}$ The nomination-induced ideological leanings of higher-level labor courts may change because of, for instance, an increase in the share of judges biased in a certain direction. As we will argue below, nomination bias is much more likely to be present at upper-level than at lower-level labor courts.
} 
panel techniques, applying a robust modelling approach that controls for both time and state fixed effects based on feasible generalized least square (FGLS) or general methods of moments (GMM) estimators.

A number of interesting results stand out. First, demand for court activity matters. We find, perhaps not surprisingly, that claims at lower-level German labor courts (Arbeitsgerichte, ArbG) are driven to a large extent by geographical, structural, and economic variables that can be linked to the demand for contract protection by employees. ${ }^{8}$ Second, however, the production of German labor courts is not driven by demand factors alone. Among the supply-side factors are personal and professional characteristics of the judges and a measure of nomination bias. In particular, there is evidence that the political "color" of the appointing state government affects court production at higher-level labor courts (Landesarbeitsgerichte, LArbG), with significant repercussions on court activity at the lower level of the judiciary. This suggests that employers and employees act rationally along the lines suggested by the theoretical model. Last not least, there is evidence that labor court activity is among the determinants of unemployment in Germany. Using the measure of nomination bias as an instrument to identify exogenous changes in labor court production, we show that an increase in court activity is associated with higher unemployment rates. The effect is both economically and statistically significant.

These results have potentially important policy implications. To the degree that evidence of nomination bias in German labor court activity might be disturbing from a normative perspective, an argument can be made for changes in the nomination process. On a more applied level, our results suggest that labor court activity is an important part of labor market regulation and deserves the attention of policy makers interested in influencing employment conditions in Germany. ${ }^{9}$ Taking the nomination process as given, this suggest that placing restrictions on the leeway of labor courts in interpreting and determining existing law may have advantages. ${ }^{10}$

\footnotetext{
${ }^{8}$ This will include wage issues as well as dismissals.

${ }^{9}$ Another implication is that indicators of labor market regulation based on readings of the law (e.g., some OECD indicators) may only give a partial picture of the actual level of regulation pertinent to the German labor market.

${ }^{10}$ Restricting the role of labor courts is also at the core of the proposal by Blanchard and Tirole (2003) on how employment protection should be reformed.
} 


\section{Related Literature}

Our paper is linked to different strands of literature. A first group of papers looks at the role labor courts play in different countries. For instance, Autor (2003), Autor et al. (2004a), and Autor et al. (2004b) show that labor court decision-making affects firing costs and employment across the Unites States. Ichino et al. (2003) indicate that Italian labor courts may vary their stance regarding what is considered employee misconduct with the state of the labor market, with possible repercussions for unemployment itself. Bertola et al. (1999) point to evidence for other OECD countries with a similar message. Focusing on German labor courts, but taking a somewhat more macroeconomic perspective, Berger (1998) reports a small negative impact of aggregated lower-level labor court activity on real GDP growth in an endogenous growth model. And Berger and Danninger (2006) estimate a Vector Error Correction model suggesting that an increase in lower-level labor court activity has a positive and surprisingly persistent impact on the unemployment rate, even after controlling for the endogeneity of the latter with regard to real activity.

Our own contribution will add to this discussion by taking a closer look at the activity of German labor courts. This area has received some, albeit scattered, attention in the literature so far. Schneider (2002) produces regression models for the activity of higher-level labor courts between 1980 and 1996, showing that court production varies systematically with the age of judges, which could be hinting at a link between productivity and individual career motives. Moreover, the court production increases with unemployment, suggesting a role for demand factors. Frick and Schneider (1999) also report that the number of dismissal conflicts at German labor courts at the lower level in the years 1964 to 1996 is affected by regional labor market conditions. Finally, Goerke and Pannenberg (2005) show, based on German survey (GSOEP) data, that the number of dismissal conflicts and their resolution are systematically influenced by employment protection legislation (which labor courts implement) and the tax-treatment of severance payments.

\section{Recruitment of Judges}

The presence of ideologically biased court or judges requires a non-random process through which judges are appointed - a condition that seems to be fulfilled in the German case for higher courts, including higher-level labor courts (i.e., LArbGs), where the nomination process is dominated by elected officials. In what follows, we will give a brief description of the nomina- 
tion process for higher-level labor courts and argue that, for various reasons, lower-level labor courts are less likely to be subject to nomination bias.

The nomination process for higher-level labor courts is dominated by elected officials, with some limited variation in the institutional detail. ${ }^{11}$ Higher-level labor courts are organized at the state (Länder) level, with the state governments, often represented by the Minister of Justice, being the principle authorities charged with appointing judges. ${ }^{12}$ In some states like Bayern, Nord-Rhein Westfalen, Niedersachsen or Mecklenburg-Vorpommern, the executive alone appoints the judges. In other states, a selection committee (Richterauswahlausschuss) encompassing mostly members of the states' parliaments, judges, representatives of interest groups, and lawyers, votes on the executive's suggested appointee (Berlin and Schleswig-Holstein). In yet other cases, the selection committee jointly decides with the state government on the appointment (Bremen, Hamburg, Hessen, and Brandenburg). Where the executive power decides in collaboration with representatives of the court system, arbitration committees are in place (Baden-Württemberg, Rheinland-Pfalz, and Saarland).

Virtually in all cases, however, there is room for ideological interests playing a role. Where the executive is not directly involved in the appointment itself, members of parliament are. Parliamentary selection committee members are elected by the state parliament itself, all but guaranteeing that the currently governing party is represented in these committees. Moreover, with the exception of Rheinland-Pfalz, parliamentary members constitute the relatively largest group in the selection committee followed by the representatives of the judges. Similarly, arbitration committees include members of parliament (Baden-Württemberg, Rheinland-Pfalz) or representatives of the executive (Saarland).

Thus, it would seem that the process of appointing higher-level court judges has the potential to be strongly political in nature and, as a consequence, may give rise to a nomination bias. A plausible hypothesis is that, as a result of this process, the appointed higher-level labor court judges are likely to resemble the political leaning of the ruling or dominating government party at the time of the appointment. This is an empirically testable hypothesis, and the following section will use a theoretical model to explore

\footnotetext{
${ }^{11}$ In the empirical section, we will pick up any cross-section variation of this type using fixed effect methods.

${ }^{12}$ Teubner (1984) provides a survey of the appointment procedures for the West German states until the beginning of the 1980s. Further information including the appointment procedures in the Neue Länder can be found in the states' constitutional laws (Länderverfasssungen) as well as in the states' laws that regulate the system of judges (Richtergesetze).
} 
its implications more fully.

There are a number of reason to believe that ideological bias is mostly restricted to higher-level labor courts. First, lower-level labor courts (i.e., ArbGs), while handling the brunt of labor court production overall, are mostly concerned with the implementation of case-based labor law, developed by the higher level of the judiciary. ${ }^{13}$ This should render lower-level labor courts less interesting than ligher-level courts from a political perspective. Second, and perhaps more importantly, there are theoretical reasons pointing in the same direction. When selecting candidates for entry level positions in the judiciary - which will, as a rule, mean at the lower-level courts - there is, as a rule, little or no information on the political stance of the candidates. This changes, however, over the course of a career, as judges interpret law on the job (see, inter alia, Levy (2005)), potentially revealing information on their ideological leanings. Once relevant information on the characteristics of judges is available, a politically charged appointment process for upper-level court positions is likely to take it into account. This view is supported by recent evidence that policymakers have an interest in an (from their perspective) 'optimal' level of judicial independence in order to bind follow-up policymakers' freedom to choose by appointing life-time judges (Hanssen (2004)).

\section{The Model}

\section{Setup}

We model the decision process of workers and firms in the tradition of an economic analysis of legal disputes (see, e.g., Cooter and Rubinfeld (1989) or Daughety (2000)). Figure 1 gives an overview over the setup. The model encompasses four stages. The starting point is a dispute over a labor contract, for instance because of a wage cut or a dismissal of a worker by a firm. Then, at stage $\# 1$, the worker and firm decide on whether to agree to a pre-court settlement or take the matter before the lower-level labor court. If no agreement can be reached, the parties re-convene before the court. After having learned about certain characteristics of the case, the worker and firm will either agree to an on-court settlement or ask for a verdict (stage \#2). Once the verdict is known, the worker and firm either accept the ruling or appeal it, taking the case to the higher-level labor court (stage \#3). Finally, at stage \#4 of the model, worker and firm decide to either seek a court

\footnotetext{
${ }^{13}$ In interviews, practitioners characterized lower-level labor courts as being staffed by predominantly young, first-time judges, hired more or less straight from university. One expert saw the role of the lower-level courts mostly as a "filter" to reduce the caseload.
} 
settlement or to opt for a higher-level court ruling. Worker and firm are forward-looking and take into account the entire legal process when making decisions.

Before discussing the four decision stages in greater detail, we introduce some notation to help us capture the idea of nomination bias with regard to the characteristics of a labor dispute. To simplify, assume that all relevant aspects of a labor court case can be captured by an (one-dimensional) indicator in the range $[-a, a]$, where $a$ is a positive number. At the beginning, nature randomly draws a case $\tilde{x}$ from an interval $[-a, a]$ with probability $g(\tilde{x})=\frac{1}{2 a}$. We assume that a case decided in favor of the worker will yield positive utility for the worker but negative utility for the firm and vice versa.

Workers and firms confronted with a case $\tilde{x}$ know that judges are heterogenous with respect to their personal perception of how the issue should be handled. While we assume that workers and firms do not know the type of a single judge, they are aware of the distribution of types. Types shall exist on the interval $[-a, a]$ with density

$$
f(x)=\frac{1}{2 a}+\theta x
$$

where $-1 / 2 a^{2} \leq \theta \leq 1 / 2 a^{2}$. Suppose, a worker and a firm are confronted with a case $\tilde{x}=0$, then the worker would expect that all types of judges in the interval $[-a, 0]$ would be in favor of his case, whereas the firm would expect all judges of types $[0, a]$ supporting its case. Thus, the probability that a case $\tilde{x}$ will be judged in favor of a worker follows by integration of equation (1) as

$$
F(\tilde{x})=\frac{1}{2 a} \tilde{x}+\frac{1}{2}+\frac{1}{2} \theta\left(\tilde{x}^{2}-a^{2}\right) .
$$

We will use the parameter $\theta$ to model ideologically biased judges with $\theta=0$ referring to the unbiased case, that is, the case of no nomination bias. If nomination bias exists, it can take two directions: positive values of $\theta$ lower a worker's probability of winning a given case $\tilde{x}$. Negative values of $\theta$ introduce a bias against the firm. 


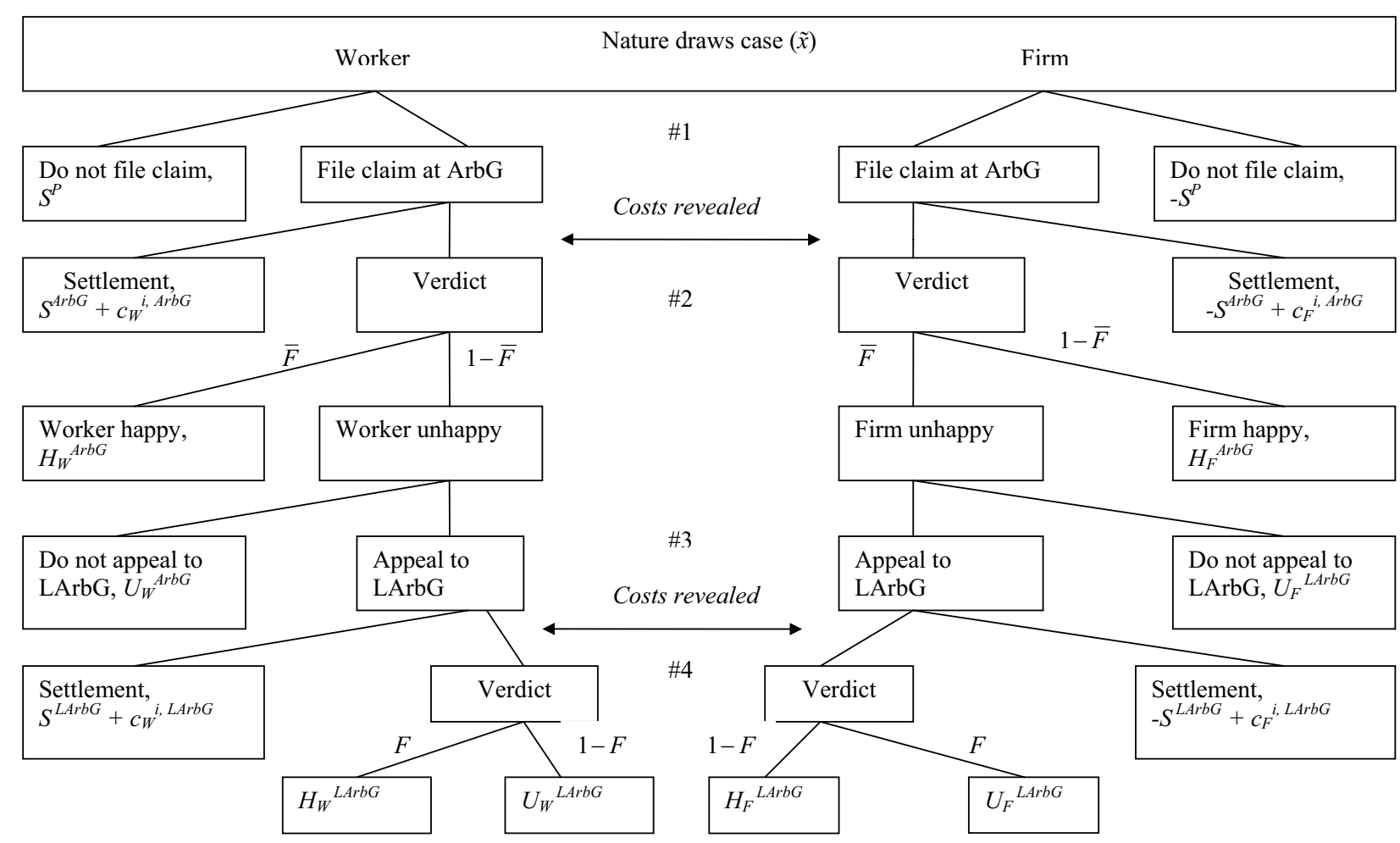

Figure 1: Worker and Firm Decisions on the Way to Higher-Level Labor Courts 


\section{Decisions}

Solving the model recursively, we will focus first on stage $\mathbf{\# 4}$, where the firm and worker decide whether to agree on a settlement at the higher-level labor court (LArbG) or seek a court decision. For the worker it would be advantageous to agree to a settlement if

$$
F(\tilde{x}) H_{W}^{L A r b G}-(1-F(\tilde{x})) U_{W}^{L A r b G}-c_{W}^{i, L A r b G}<S^{L A r b G},
$$

with $i=h, l$. The left hand sides depicts the expected payoffs of a trial net of trial costs. The right hand side summarizes the transfers from the firm to the worker in case of a settlement. $F(\tilde{x})$ is the probability that a case $\tilde{x}$ will be judged in favor of a worker, $H_{W}^{L A r b G}$ is the worker's payoff associated with a court ruling in his favor, and $-U_{W}^{L A r b G}$ is the worker's payoff when the court rules otherwise.

In addition, net-benefits will depend on the costs of a trial. We assume that the costs of bringing a case before higher-level courts are revealed only after the claim has been filed (a similar assumption will be introduced for the lower-level courts). Behind this assumption is the fact that the cost of bringing a labor contract to court entails both transaction and opportunity costs - with the latter playing a dominant role in the German case. Court and attorney fees are often low and covered by insurance or provided for by trade unions for their members. What seems to be more relevant are opportunity costs to the worker and the firm. Depending on the issue it may take considerable time until a verdict is reached, which would reduce workers' opportunity to search for another job or engage in other activities. The exact amount of time, however, will, as a rule, be hard to gauge ex ante. At court both parties and the judge(s) meet in order to discuss the case first. During this process ( $G$ "uteverhandlung) both the plaintiff and the defendant learn more about the legal situation, and it is only then that (most of) the uncertainty surrounding the opportunity cost is resolved.

More formally, we assume that ex ante, the worker and the firm only know that those costs can either be high $c_{W}^{h, L A r b G}$ or low $c_{W}^{l, L A r b G}$, where the superscripts stand for high and low costs at the higher-level labor court.

If the worker agreed on a settlement at the higher-level labor court, the payoff would be a fixed value $S^{L A r b G}$. Following the literature (Cooter and Rubinfeld (1989)), we abstract from transaction costs and assume that settlements take the simple form of a transfer from one party (usually the firm) to the other party.

Equivalently, the firm will opt to seek a settlement before the higher-level labor court if

$$
(1-F(\tilde{x})) H_{F}^{L A r b G}-F(\tilde{x}) U_{F}^{L A r b G}-c_{F}^{i, L A r b G}<-S^{L A r b G},
$$


where the interpretation of all terms is symmetrical to the case of the worker. That is, $H_{F}^{L A r b G}$ is the firm's payoff associated with a favorable court ruling, $-U_{F}^{L A r b G}$ is the firm's payoff when the court rules otherwise, and the cost associated with seeking a court decision can be either high $\left(c_{F}^{h, L A r b G}\right)$ or low $\left(c_{F}^{l, L A r b G}\right)$. Note that probabilities for a favorable or non-favorable court decision for the firm mirror the ones for the worker.

A settlement requires that both inequalities hold simultaneously. As a consequence, a settlement will be reached if the expected joined surplus exceeds the expected surplus in case of a non-cooperative solution. Adding both left-hand and right-hand sides of equations (2) and (3) we have

$$
\begin{aligned}
& F(\tilde{x}) H_{W}^{L A r b G}-(1-F(\tilde{x})) U_{W}^{L A r b G}-c_{W}^{i, L A r b G} \\
& +(1-F(\tilde{x})) H_{F}^{L A r b G}-F(\tilde{x}) U_{F}^{L A r b G}-c_{F}^{i, L A r b G}<0 .
\end{aligned}
$$

Further rearranging equation (4) yields

$$
\begin{aligned}
& F(\tilde{x})\left(H_{W}^{L A r b G}+U_{W}^{L A r b G}-H_{F}^{L A r b G}-U_{F}^{L A r b G}\right) \\
& +H_{F}^{L A r b G}-U_{W}^{L A r b G}<c_{W}^{i, L A r b G}+c_{F}^{i, L A r b G} .
\end{aligned}
$$

An implication of equation (5) is that a change in the nomination bias will affect the number of settlements at the higher-level labor court if workers and firms have different stakes in the case. For instance, if firms' stakes are higher $\left(H_{F}^{L A r b G}+U_{F}^{L A r b G}>H_{W}^{L A r b G}+U_{W}^{L A r b G}\right)$, a higher-level labor court biased toward the interests of firms will reduce the joined surplus on the left hand side of equation (5). Consequently, more settlements should be observed. Ultimately, however, this is an empircal question. ${ }^{14}$

Proceeding recursively through the model (see Figure 1), at stage \#3, the worker and the firm decide whether to accept a lower-level court (ArbG) ruling or continue the legal process by filing an appeal to the higher-level labor court. Should the worker and the firm be content with the lower-level verdict, there is an associated fixed payoff $-U_{W}^{A r b G}$ and $-U_{F}^{A r b G}$, respectively. If either of the two parties appeals, however, there are again opportunity costs to consider, which can be either high or low $\left(c_{j}^{h, L A r b G}\right.$ or $\left.c_{j}^{h, L A r b G}\right)$ with probabilities $q_{j}^{L A r b G}$ and $1-q_{j}^{L A r b G}$, respectively, for $j=W, F$. Similar to

\footnotetext{
${ }^{14}$ The precise level of the settlement payments at higher-level labor courts does not play a role for this effect because the net-transfer is assumed to be zero. Endogenizing settlement payments would involve making assumptions on how excactly a change in nomination bias would impact the cooperative solution, for instance through changes in the threat values of the firm and the worker in the bargaining over the transfers. There is, however, little or no information on actual payments which would allow us to confront predictions of such a model extension with the data.
} 
stage \#4, the payoffs of relying on court action will be uncertain and depend on the course of events. And, as before, the possible existence and direction of a nomination bias at the higher-level labor court will influence the outcome.

At stage \#2, similar to stage \#4, we will observe a trial if the joined surplus of the non-cooperative game is larger than the value from the cooperative solution. As before, the value of the latter is zero because the settlement payments $S^{A r b G}$ are transfers from one party to the other and transactions costs are neglected. Note, that the absence of nomination bias at the lower-level labor court (see Section 2) implies $\theta=0$. Thus, if the case is decided by court verdict, the worker wins with probability $\left.F(\tilde{x})\right|_{\theta=0}$ receiving a payoff $H_{W}^{A r b G}$, and looses with probability $1-\left.F(\tilde{x})\right|_{\theta=0}$ receiving an uncertain payoff depending on the decisions to be taken at stages \#3 and \#4. ${ }^{15}$ In addition the worker has to carry the court $\operatorname{costs} c_{W}^{i, A r b G}$ with $i=h, l$. Equivalently, the firm receives a payoff $H_{F}^{A r b G}$ from a favorable court ruling with probability $1-\left.F(\tilde{x})\right|_{\theta=0}$ and a to-be-determined uncertain payoff otherwise with probability $\left.F(\tilde{x})\right|_{\theta=0}$. As a consequence, if nomination bias influences decisions at stages \#4 and \#3, this will be the case at \#2 as well. ${ }^{16}$

At stage $\# \mathbf{1}$, the worker and firm decide whether to file a claim to the lower-level labor court or to reach a pre-court settlement. It is probably safe to assume that some direct worker-firm interaction precedes court procedures, even though empirically it is workers rather than firms that bring labor disputes to lower-level courts. In principle, a firm faces a choice of approaching the worker pre-court, solving the dispute through a pre-court settlement or allowing the dispute to continue in front of the judges, with a possible continuation at a biased higher-level labor court. The worker will have to determine whether to accept a settlement suggested by the form or seek a lower-level court decision.

As a consequence, worker-firm interaction at stage \#1 can be modelled akin to stages \#4 and \#2: the dispute will go to trial if the joint surplus of the non-cooperative game exceeds the cooperative value based on a settlement. Absent transaction costs, the cooperative value is zero. Pursuing a filed claim until a settlement or verdict is reached entails costs. Ex ante, those costs can either be high $c_{j}^{h, A r b G}$ or low $c_{j}^{l, A r b G}$ for $j=W, F$ with probabilities $q_{j}^{A r b G}$ and $1-q_{j}^{A r b G}$, and the magnitude of those costs is revealed only once the claim is filed at the lower-level labor court. On the benefit side, the worker and firm are faced with uncertain payoffs depending on the later stages of the game.

\footnotetext{
${ }^{15}$ Note that in Figure 1, we use the notational convenience $\left.\bar{F}(\tilde{x}) \equiv F(\tilde{x})\right|_{\theta=0}$.

${ }^{16} \mathrm{~A}$ more detailed discussion of the decisions involved at stage \#3 as well as stages \#2, \#1 can be found in Appendix 1.
} 
And, as before, it is through this channel that a possible nomination bias at the higher-level labor court will influence these payoffs.

\section{Implications}

Introducing nomination bias at the higher court level - that is, allowing $\theta$ in equation (1) to deviate from zero and distorting workers' and firms' probability to win a case - has a number of quantitative and structural implications for the activity of both lower- and higher-level labor courts.

The previous Section showed that the existence and direction of a higherlevel labor court nomination bias, while directly effective only late in the legal process, influences all stages of the worker's and firm's decision-making. This holds true even at stage \#1 and despite the fact that, following our discussion of the appointment process in Section 2, there is no nomination bias at lowerlevel labor courts. The reason is simply that the possibility of an appeal to the higher-level court, where a nomination bias may exist, is part of the decision to forgo a pre-court settlement and to seek a ruling by the lower-level court. Even though it is far from assured that a particular case will actually reach the higher court level (not least because the outcome is endogenously determined in the model), there is a certain probability that it will. As a consequence, the nomination induced ideological leanings of the higher-level labor court will influence the joined surplus of the non-cooperative game already at stage \#1. A similar logic applies to stages \#2 and \#3. In all cases, a change in the direction of the nomination bias affects the joined surplus of the non-cooperative solution - the results of the claim to a lowerlevel court at stage $\# 1$, the results of the lower-level court verdict at stage $\# 2$, and the outcome of an appeal to the higher-level court at stage \#3with the potential to change the respective decisions of the worker and firm.

The following proposition summarizes these hypotheses.

Proposition: In the presence of nomination bias at higher-level labor courts, a change in its direction will distort workers' and firms' probability of winning a case. As a consequence, we will observe a change in the

- share of higher-level labor court settlements to overall higher-level cases at stage \#4 ( $\left.\equiv \mathrm{H}_{4}\right)$

- share of lower-level labor court verdicts that is appealed at stage \#3 (三H3)

- share of lower-level labor court settlements to overall lower-level cases at stage \#2 (三H2) 
- number of claims filed at lower-level labor court at stage \#1 ( $\equiv H 1)$.

\section{Empirical Results}

\subsection{The Data}

In taking the theoretical results to the data, we rely on four principal sources. First, we use information on the activity of lower-level and higher-level labor courts provided by the Bundesministerium für Wirtschaft und Arbeit. The data includes information on the number of actual decisions and the structure of these decisions, that is, a breakdown into decision by verdict, settlement, and appeals, at lower-level labor courts (ArbG) and higher-level labor courts (LArbG) by state and year. A second type of data stems from a bi-annual publication by the German Association of Judges (Richterbund), providing details on personal characteristics of higher-level labor court judges, in particular the date of their nomination to the court, their age, sex, and academic degree by state and year. Third, we collected information on state governments, including the party affiliation of the Prime Minister and the Minister of Justice, and the distribution of parliamentary seats within coalition governments in a given year across states. ${ }^{17}$ Combining the year of nomination to a higher-level labor court with a measure of the dominating political color of the relevant state government allows us to identify the possible political nomination bias of a judge. Finally, we collect a number of structural and economic variables, some time-variant some constant over time, including state size, population, real GDP growth, from the federal and state statistical offices and other sources. Details regarding all data used in the empirical section are available in Appendix 2. Table 1 provides summary statistics and short descriptions of key variables.

Figures 2 and 3 illustrate that there is ample variance, across states and time, in our indicators of court production as well as in bias, our measure of nomination bias. The court production variables are constructed to allow testing the hypotheses introduced in the previous Section (see Table 1; we provide additional discussion below). The variable bias indicates the percentage share of judges in a given higher-level labor court that was nominated by a state government with a conservative (CDU or CSU) Prime Minister. If the nomination process does indeed bias the selection of judges to higherlevel courts toward the governing party, we should expect bias to indicate the average conservative ideological leaning of the judges constituting the higher-level labor court.

\footnotetext{
${ }^{17}$ We discuss alternative measure of the political color of government below.
} 
Table 1: Summary Statistics

\begin{tabular}{|c|c|c|c|c|c|}
\hline Variable & Description & Mean & Min & Max & Std.err. \\
\hline claims_arbg & $\begin{array}{l}\text { Claims processed at lower-level } \\
\text { courts }\end{array}$ & 33,537 & 3,286 & 137,290 & 28,605 \\
\hline settle_arbg & Settlements at lower-level courts & 13,442 & 1,130 & 73,075 & 12,562 \\
\hline settle_ratio_arbg & $\begin{array}{l}\text { Ratio settlements lower-level } \\
\text { courts/claims processed lower- } \\
\text { level courts }\end{array}$ & 0.41 & 0.15 & 0.60 & 0.08 \\
\hline verdicts_arbg & Verdicts at lower-level courts & 2,911 & 281 & 12,168 & 12,562 \\
\hline appeals_larbg & Appeals to higher-level courts & 1,441 & 129 & 6,661 & 1,246 \\
\hline appeals_ratio_larbg & $\begin{array}{l}\text { Ratio appeals/verdicts at lower- } \\
\text { level courts }\end{array}$ & 0.51 & 0.23 & 0.89 & 0.10 \\
\hline settle_larbg & $\begin{array}{l}\text { Settlements at higher-level } \\
\text { courts }\end{array}$ & 458 & 29 & 2,271 & 426 \\
\hline settle_ratio_larbg & $\begin{array}{l}\text { Ratio settlements/appeals to } \\
\text { higher-level courts }\end{array}$ & 0.32 & 0.13 & 0.54 & 0.07 \\
\hline bias & $\begin{array}{l}\text { Share of higher-level court judges } \\
\text { nominated by conservative State } \\
\text { governments }\end{array}$ & 0.52 & 0 & 1 & 0.42 \\
\hline$d o c$ & $\begin{array}{l}\text { Share of judges holding doctoral } \\
\text { degree }\end{array}$ & 0.32 & 0 & 0.8 & 0.19 \\
\hline age & Average age of judges & 52.9 & 43.8 & 63.6 & 3.1 \\
\hline sex & Average share of female judges & 0.12 & 0 & 0.5 & 0.12 \\
\hline area & $\begin{array}{l}\text { Dummy; } 1 \text { if State area above av- } \\
\text { erage State size }\end{array}$ & 22,593 & 404 & 70,549 & 20,181 \\
\hline pop & Population in 1,000 & 5,425 & 660 & 18,069 & 4,789 \\
\hline$u r$ & $\begin{array}{l}\text { Unemployment rate (unem- } \\
\text { ployed/labor force) }\end{array}$ & 0.087 & 0.004 & 0.241 & 0.055 \\
\hline gdp_real & $\begin{array}{l}\text { Dummy; } 1 \text { if State real GDP } \\
\text { above average State }\end{array}$ & 114,731 & 13,502 & 445,836 & 108,105 \\
\hline growth & Real GDP growth & 0.043 & -0.036 & 0.258 & 0.045 \\
\hline industry & Industry share in total GDP & 0.336 & 0.174 & 0.528 & 0.077 \\
\hline
\end{tabular}



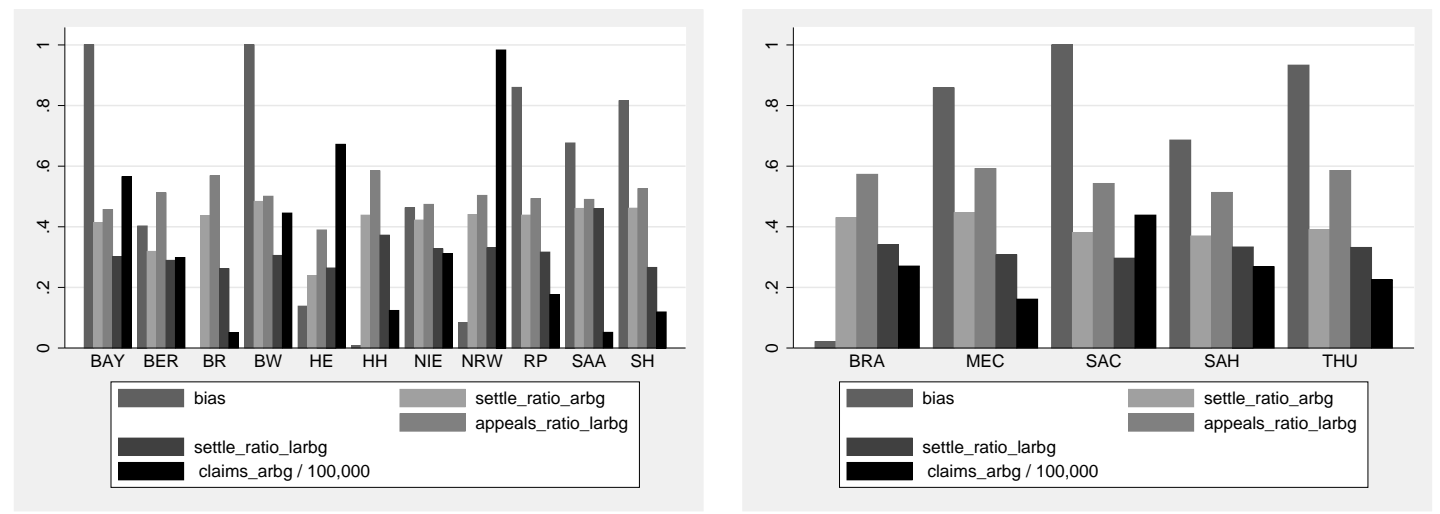

Figure 2: Indicators of Law Production and Nomination Bias (State Means - left panel for West and right panel for East states.)

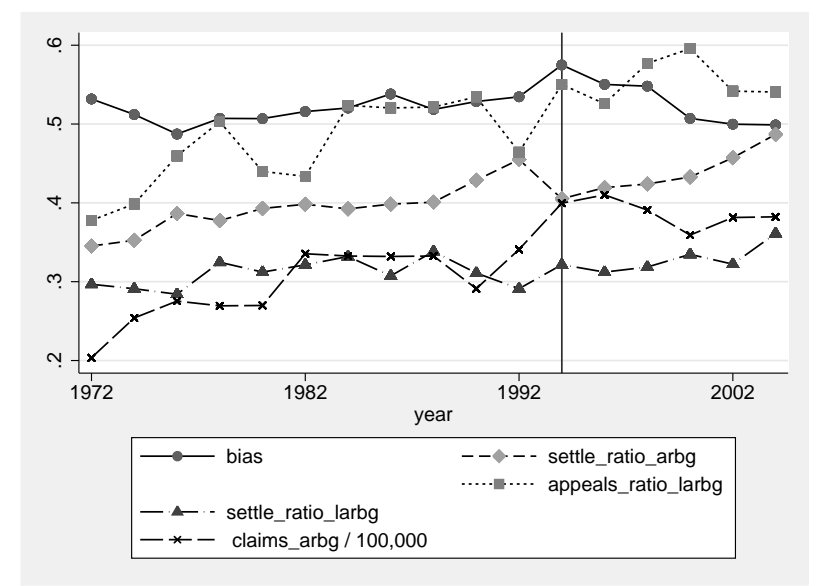

Figure 3: Indicators of Law Production and Nomination Bias (Sample Means) 
The results in what follows are quite robust with regard to alternative measures of nomination bias. While the party affiliation of the Prime Minister gives the clearest indication of the dominating overall political leaning of a government, we also experimented with other measures of state governments' ideological direction, including the party affiliation of the Minister of Justice or weighted measures that take into account the share of parliamentary seats held by the parties involved in a coalition government. All yield broadly similar results. ${ }^{18}$ For the sake of clarity and because it is probably the most direct way to test the underlying hypothesis, we focus the presentation on the bias indicator as defined.

The data allow constructing an unbalanced panel, including 16 crosssections (states) with about 190 bi-annual observations for the eleven West German states, starting 1972 and ending 2004, and about 25 bi-annual observations for the five East German states, starting in 1996 and ending in 2004. In general, the results below do not change significantly if we exclude the East German states from the regressions. ${ }^{19}$

Our econometric approach stresses robustness. With modified Wald statistics indicating the possible presence of heteroscedastic errors, and first-degree autocorrelation in the residuals in some instances, we opted for using a feasible least square estimator to provide robust standard errors. ${ }^{20}$ Moreover, all models include a comprehensive set of cross-section and time fixed effects to capture any common period-specific factors and any time-invariant heterogeneity not picked up by other explanatory variables. Standard panel-based unit root tests indicate that the time series used in the econometric exercises are stationary; and the same holds for the residuals of the estimated models. $^{21}$

\subsection{Regression Results}

\section{H1: Claims at Lower-Level Labor Courts}

Hypothesis 1 states that, in the presence of nomination bias, a change in the relative number of judges appointed by conservative governments to higherlevel labor courts will distort workers' and firms' probability of winning a case. As a consequence, we should observe a change in (the log of) the overall

\footnotetext{
${ }^{18}$ Alternative results available on request.

${ }^{19}$ Additional results available on request. We exclude East German states in the year 1994 mostly for reasons of GDP data reliability.

${ }^{20}$ We used the xtgls package with options panels(heteroskedastic) and corr(psar) implemented in Stata 9.1, with the latter assuming a panel specific AR process in the errors.

${ }^{21} \mathrm{~A}$ majority of tests included in the EViews 5.1 package rejects non-stationarity at conventional levels. Results were particularly clear-cut for the residuals.
} 
number of claims annually processed at lower-level labor courts at stage \#1 $(\log ($ claims_arbg $))$. Table 2 shows the results from a FGLS regression testing the hypothesis.

In addition to the bias variable, the estimated model includes a number of plausible controls capturing relevant demand-side determinants of labor court activity at the lower court level. We will explain these controls and discuss the underlying intuition before turning to the regression result.

The variables area and $g d p_{-}$real are qualitative indicators of state size. The former takes the value of 1 for states larger than the average (and is 0 otherwise) and the latter takes the value of 1 for states with a real GDP level exceeding the state average (0 otherwise). ${ }^{22}$ Yet another indicator of size is $\log (p o p)$, the log of the state population in a given year. While there is no formal theory linking size and labor court activity, its is probably safe to speculate that the demand for court services is higher in highly urbanized, area-wise smaller states, including the so-called city states of Hamburg, Bremen, and Berlin, which would imply a negative sign on the area variable. On the other hand, we may expect economically larger states with larger populations to show more demand for labor court activity, implying a positive impact of the GDP- and population-based variables. ${ }^{23}$

In addition to its relative level, the change in state real GDP may affect labor court activity. To allow for delayed impact, we include both contemporaneous and lagged GDP growth, growth and growth-1, as indicators of the regional business cycle. We would expect real growth to be negatively related to labor court demand - although the inclusion of fixed time effects may render these variables less relevant. The variables industry and indus$t r y_{-1}$ are time-variant indicators measuring the current and lagged share of the manufacturing sector in the economy. Because manufacturing is the area in the economy in which trade unions are strongest, and unions often lend support to court claims by unionized workers, we would expect to see labor court activity to be higher in states and periods with a larger manufacturing sector.

Table 2 shows that, with the exception of growth and growth $_{-1}$, the set of control variables has a significant impact on lower-level court activity in line with the arguments introduced above. More importantly, however, the

\footnotetext{
${ }^{22}$ In both cases the definition does not exclude time-variation per se (not least due to German unification), but de facto both variables hardly change: area is a constant in all cases and gdp_real changes only (from 0 to 1) for Lower Saxonia (Niedersachsen) and Hesse (Hessen) in the early 1980s.

${ }^{23}$ We also experimented with models including the (log of) the workforce or the number of employees and unemployed. However, in general, these specifications are dominated by the set of demand-side variables described above.
} 
Table 2: Claims At Lower-Level Labor Courts (H1)

\begin{tabular}{|c|rl|}
\hline \multicolumn{3}{|c|}{ Dependent variable: $\log ($ claims_arbg) } \\
\hline & coef. & Std.err. \\
\hline bias & -0.12 & $0.04^{* * *}$ \\
area & -1.02 & $0.19^{* * *}$ \\
log(pop $)$ & 1.48 & $0.11^{* * *}$ \\
gdp_real & 0.08 & $0.04^{* *}$ \\
growth & 0.19 & 0.29 \\
growth -1 & 0.11 & 0.15 \\
industry & 0.55 & 0.65 \\
industry-1 & 1.54 & $0.62^{* *}$ \\
\hline Time and state fixed effects & \multicolumn{2}{|c|}{ Yes } \\
\hline number of obs. & \multicolumn{2}{|c|}{199} \\
\hline
\end{tabular}

Note: Estimated with feasible generalized least squares allowing for heteroscedasticity of errors across panels and $\mathrm{AR}(1)$ autocorrelation of errors within panels.

regression results are indicative of a highly significant effect of the bias variable on lower-level court production - that is, we cannot reject the hypothesis that there is a nomination bias influencing German labor court activity at the lower level.

The negative sign suggests that less cases are filed with lower-level labor courts when the share of high-level judges nominated by conservative dominated state governments increases. Returning to the theoretical model of Section 4, a possible interpretation of the result rests with the forwardlooking decisions of workers and firms. Both parties will take into account the consequences of a higher bias further up the legal path and adjust the expected payoffs from legal action - workers will expect their payoffs to decline and firms will expect an increase. The estimation result indicates that, at the margin, workers react more strongly to this change than firms. As a consequence, the expected surplus from the non-cooperative solution will fall and fewer cases are taken to court.

Evaluated at sample means, the elasticity of log(claims_arbg) with regard to bias is about -0.06 , implying that a one percent increase in the number of judges appointed by a conservative state government reduces processed claims at lower-level courts by about 6 basis points. 


\section{H2: Share of Settlements At Lower-Level Labor Courts}

Hypothesis 2 argues that in the presence of nomination bias a change in the relative number of higher-level judges nominated by conservative state governments will significantly affect the share of settlements in overall lowerlevel labor court cases at stage \#2 . Table 3 presents two alternative models testing the hypothesis. The first regression explains the ratio of settlements to overall decisions, settle_ratio_arbg, by the set of demand-side variables introduced in Table 2 as well as bias. We would expect these variables to influence the settlement ratio mostly through the denominator, not least because the theoretical model suggests that, given a filed claim at the lower court level, the decision to accept a settlement is forward-looking, that is, oriented toward higher-level courts. This should make it mostly independent of variables conditioning the demand for labor court services at the lower level. Thus, as a robustness test, the second model explains the log of the level of settlements with the log of overall processed lower-level court decisions, claims_arbg, as well as bias. ${ }^{24}$

Table 3 shows a significant impact of bias in both specifications, lending further support to the hypothesis that nomination bias influences German labor court activity. In the first model, the demand-side variables enter (mostly) with the opposite sign of Table 2, suggesting that their influence on the settlement ratio indeed rests mostly on the overall number of claims in the denominator. The number of settlements is positively correlated with the overall number of claims to lower-level courts in the second model.

According to Table 3, firms and workers tend to settle more of their lowerlevel court cases when faced with the more firm-friendly labor courts at the next level. Again, the sign can be rationalized on the basis of the theoretical model: an increase in bias will make it less attractive for forward-looking workers to ask the lower-level court for a verdict, which would open the door to a continuation of the legal proceedings in front of a more firm-friendly higher-level court. A similar effect is at work with firms, albeit in the opposite direction. The empirical results suggest that the marginal impact on workers is stronger, leading to a reduction of the expected non-cooperative surplus. Evaluated at sample means, the elasticity of settle_ratio_arbg with regard to bias is about 0.04 , and 0.03 in the specification which uses settle_arbg as the dependent variable.

\footnotetext{
${ }^{24}$ Economically, the model is similar in nature to the first, with the exception that it avoids the reduced form (by using claims_arbg rather than its determinants) and does not restrict the coefficient for claims_arbg to unity.
} 
Table 3: Share of Settlements At Lower-Level Labor Courts (H2)

\begin{tabular}{|c|c|c|}
\hline & $\begin{array}{l}\text { Dependent variable: } \\
\log (\text { settle_ratio_arbg })\end{array}$ & $\begin{array}{c}\text { Dependent variable: } \\
\text { log }(\text { settle_arbg })\end{array}$ \\
\hline & coef. $\quad$ Std.err. & coef. $\quad$ Std.err. \\
\hline log(claims_arbg) & & $0.720 .04^{* * *}$ \\
\hline bias & $0.03^{* *}$ & $0.03^{* *}$ \\
\hline area & $0.12^{* * *}$ & \\
\hline $\log (p o p)$ & $0.10^{* * *}$ & \\
\hline$g d p \_r e a l$ & 0.03 & \\
\hline growth & 0.07 & \\
\hline growth-1 $_{-1}$ & 0.02 & \\
\hline industry & $0.46^{* * *}$ & \\
\hline industry $_{-1}$ & $0.81 \quad 0.41^{* *}$ & \\
\hline Time and state fixed effects & Yes & Yes \\
\hline number of obs. & 199 & 211 \\
\hline
\end{tabular}

Note: Estimated with feasible generalized least squares allowing for heteroscedasticity of errors across panels and $\mathrm{AR}(1)$ autocorrelation of errors within panels.

\section{H3: Share of Lower-Level Court Verdicts Appealed}

Hypothesis 3 states that, in the presence of nomination bias, a change in bias should trigger a change in the share of lower-level court verdicts that is appealed at stage \#3. The empirical model deviates from the previous ones in that it excludes demand-side variables. The rationale is that there is little reason to believe the appeal-verdict ratio (log(appeals_ratio_larbg)), which captures decision clearly oriented toward higher-level courts, to be influenced by determinants of overall claims to lower-level courts. For the same reason, it makes sense to introduce a set of variables describing potentially influential higher-level labor court characteristics other than bias into the model namely the share of judges holding a doctoral degree $(d o c)$, the average age of judges (age), and the average share of female judges (sex) in a particular year and state. Previous work suggests that judges with a doctoral degree are more productive, and there also seems to be some evidence for a negative impact of age on productivity (see Schneider (2005)).

As in Table 3, we run two alternative models, one with log(appeals_ratio_larbg) as the dependent variable, and one with the overall number of appeals in logs $(\log ($ appeals_larbg $))$ on the right-hand-side and log(verdicts_arbg) as an additional left-hand-side variable. As before, the second model serves 
Table 4: Share of Lower-Level Court Verdicts Appealed (H3)

\begin{tabular}{|c|c|c|c|}
\hline & $\begin{array}{l}\text { Dependent variable: } \\
\text { log(appeals_larbg) }\end{array}$ & $\begin{array}{l}\text { Dependent } \\
\text { log(appeals_t }\end{array}$ & $\begin{array}{l}\text { variable: } \\
\text { atio_larbg) }\end{array}$ \\
\hline & coef. $\quad$ Std.err. & coef. & Std.err \\
\hline bias & $0.04^{* * *}$ & 0.08 & $0.03^{* * *}$ \\
\hline $\log ($ verdicts_arbg $)$ & $0.06^{* * *}$ & & \\
\hline$d o c$ & $0.00^{* * *}$ & -0.02 & $0.00^{* * *}$ \\
\hline $\operatorname{sex}$ & -0.17 & -0.10 & 0.11 \\
\hline age & $-0.01 \quad 0.00^{* * *}$ & -0.01 & $0.00^{*}$ \\
\hline Time and state fixed effects & Yes & \multicolumn{2}{|c|}{ Yes } \\
\hline number of obs. & 211 & \multicolumn{2}{|c|}{211} \\
\hline
\end{tabular}

Note: Estimated with feasible generalized least squares allowing for heteroscedasticity of errors across panels and $\mathrm{AR}(1)$ autocorrelation of errors within panels.

mostly as a robustness check. However, without a reason to suspect that labor court characteristics influence only the verdicts ratio, we opted to include doc, age, and sex in both specifications.

Again, the results summarized in Table 4 do not allow rejecting the hypothesis of nomination bias: in both models, bias has a significantly positive impact on appeals, implying that more lower-level court decisions are appealed as the share of higher-level judges nominated by conservative state governments increases. From a theoretical perspective, this suggests that, in this case, the marginal reaction of firms dominates the reaction of workers to a change in higher-level court bias. ${ }^{25}$ Evaluated at sample means, the elasticity of $\log$ (appeals_larbg) with regard to bias is about 0.1, and 0.04 for the model which uses the total number of appeals as the dependent variable.

As to the control variables, it is interesting to note that less appeals tend to be filed if the higher-level labor court judges become more experienced in terms of age and academic credentials, perhaps because they are less likely to overturn lower-level court decisions. Moreover, an increasing share of female judges also tends to be associated with fewer appeals. Note, however, that these effects are not necessarily very robust - only doc is statistically significant at conventional levels in both specifications shown in Table 4.

\footnotetext{
${ }^{25}$ Note that, at this juncture of the model, with no cooperative settlement solution involved, firms and workers only contemplate their (individual) chance of succeeding at the next court level. See Section 4.
} 
Table 5: Share of Settlements at Higher-Level Courts ( $\left.H_{4}\right)$

\begin{tabular}{|c|c|c|c|c|}
\hline & \multicolumn{2}{|c|}{$\begin{array}{l}\text { Dependent variable: } \\
\log (\text { settle_ratio_larbg })\end{array}$} & \multicolumn{2}{|c|}{$\begin{array}{c}\text { Dependent variable: } \\
\text { log(settle_larbg })\end{array}$} \\
\hline & coef. & Std.err. & coef. & Std.err. \\
\hline bias & 0.20 & $0.04^{* * *}$ & 0.14 & $0.04^{* * *}$ \\
\hline $\log \left(a p p e a l s \_l a r b g\right)$ & & & 1.11 & $0.05^{* * *}$ \\
\hline$d o c$ & 0.01 & $0.00^{*}$ & 0.01 & $0.00^{* * *}$ \\
\hline $\operatorname{sex}$ & -0.50 & $0.11^{* * *}$ & -0.25 & $0.12^{* *}$ \\
\hline age & -0.02 & $0.00^{* * *}$ & -0.02 & $0.00^{* * *}$ \\
\hline Time and state fixed effects & \multicolumn{2}{|c|}{ Yes } & \multicolumn{2}{|c|}{ Yes } \\
\hline number of obs. & \multicolumn{2}{|c|}{212} & \multicolumn{2}{|c|}{200} \\
\hline
\end{tabular}

Note: Estimated with feasible generalized least squares allowing for heteroscedasticity of errors across panels and $\mathrm{AR}(1)$ autocorrelation of errors within panels.

\section{H4: Share of Settlements at Higher-Level Courts}

Finally, Hypothesis 4 argued that, if the presence of ideologically biased judges at higher-level labor courts distort workers' and firms' probability of winning a case, we will observe a change in the share of higher-level settlements to overall higher-level labor court cases at stage \#4. Table 5 reports the results of the now familiar specification, with the share of settlements in overall higher-level court production (settle_ratio_larbg) and the log of higherlevel settlements $(\log ($ settle_larbg $))$ as the dependent variables. In the latter case, we include the log of overall appeals to the higher-level labor court $(\log ($ appeals_larbg $))$ on the right-hand-side. Higher-level court characteristics are included in both specification.

The coefficients for sex and age turn out significantly negative in both specifications, confirming the results in Table 4. However, different from Table 4, the coefficient for $d o c$ is positive in Table 5 - albeit not significant at conventional levels in the ratio specification. This casts some doubt on the conclusion that the average academic pedigree of higher-level courts has a systematic influence on court decisions.

As to the question of nomination bias, the results in Table 5, too, point in this direction, with bias showing up significantly positive. Returning to our theoretical model, this suggests that the stakes in labor court cases are larger for firms than for workers - perhaps because of the repeated nature of the situation from the perspective of the firm. Evaluated at sample means, the elasticity of settle_ratio_larbg with regard to bias is about 0.1 , and 0.07 
when $\log ($ settle_larbg) is used as the dependent variable.

\section{Nomination Bias and Unemployment}

Finally, we discuss a simple extension of the empirical model, to explore the effect of court activity on unemployment. To that end, we estimate a model that relates the log of the unemployment rate $(\log (u r))$ to overall lower-level labor court activity (log(claims_arbg)) and a set of additional plausible and

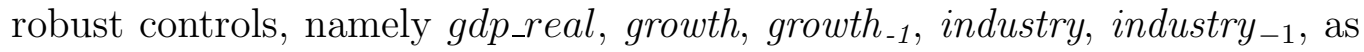
well as fixed time and cross-section effects. ${ }^{26}$

To control for the endogeneity of court activity with regard to the latter group of variables, we use a GMM approach, employing bias, our measure of the ideological leaning of German higher-level labor courts, $\log (p o p)$, and area as exogenous (i.e., excluded) instruments. ${ }^{27}$ The endogeneity controls are a straightforward extension of our earlier investigation of court activity. Moreover, to exclude the possibility of repercussions of changes in the unemployment rate on bias, we performed standard Granger causality tests (see Appendix 3). The results strongly suggest that the nomination bias of higher-level labor courts is independent from the unemployment rate. ${ }^{28}$

Table 6 presents the results. ${ }^{29}$ Test statistics are estimated heteroscedasticity- and autocorrelation-consistent. The control variables yield fairly plausible coefficients, suggesting that economically larger states suffer higher unemployment rates while higher real growth rates as well as a larger industrial sector tend to lower unemployment contemporaneously or after a certain lag. Regarding labor court activity, Table 6 indicates that an exogenous increase in the number of cases processed by lower-level labor courts has a positive impact on unemployment across time and states. The point estimate for the coefficient of $\log$ (claims_arbg) is 0.34 and statistically significant at the 1-percent level. The effect seems relevant from an economic point of view: a

\footnotetext{
${ }^{26}$ Taken together with the exogenous instruments for court activity (see the discussion below), this resembles the model used to explain Hypothesis 1 in the previous section. In addition to allowing for a consistent set of instruments for log(claims_arbg), the choice of variables is also plausible for the rate of unemployment. As argued earlier, the H1 model was constructed to capture important demand factors in court activity, including determinants for unemployment.

${ }^{27}$ In addition, court activity is instrumented by the other variables included in the model. That is, gdp_real, growth, growth ${ }_{-1}$, industry, industry ${ }_{-1}$, and the fixed time and cross-section effects serve as included instruments for log(claims_arbg).

${ }^{28}$ Indeed, the only (at least marginally) significant Granger relation indicates that causality runs from bias to unemployment. See Appendix 3 for details.

${ }^{29}$ Estimates based on the ivreg2 package for Stata. Using 2SLS instead of the GMM estimator yields a comparable coefficient for log(claims_arbg).
} 
Table 6: Explaining Unemployment with Labor Court Activity

\begin{tabular}{|c|rl|}
\hline \multicolumn{3}{|c|}{ Dependent variable: $\log ($ ur $)$} \\
\hline & coef. & Std.err. \\
\hline log(claims_arbg $)$ & 0.34 & $0.13^{* * *}$ \\
gdp_real & 0.11 & $0.05^{* *}$ \\
growth & -1.34 & $0.66^{* *}$ \\
growth_1 & -0.25 & 0.31 \\
industry & -0.35 & 1.12 \\
industry -1 & -2.66 & $1.08^{* *}$ \\
\hline Time and state fixed effects & \multicolumn{2}{|c|}{ Yes } \\
\hline number of obs. & \multicolumn{2}{|c|}{198} \\
\hline
\end{tabular}

Note: Estimated by GMM, allowing for heteroscedasticity and autocorrelation robust standard errors. See main text for a discussion of the instrument used.

1 percent increase of claims filed at lower-level labor courts increases unemployment by about $1 / 3$ percent.

The unemployment effect of labor court activity has a potentially important policy implication. The empirical evidence indicates that labor courts indeed play some role in explaining the occurrence of unemployment across states and time, even after controlling for the endogeneity of court production. Because German labor courts are said to influence labor market outcomes mainly through their influence on the effective level of regulation (and, thus, the ability of firms to adjust wages and employment), this suggests that there may be gains from restraining labor court activity.

The result is fairly robust, but a possible caveat is the simplicity of the unemployment model. The empirical model, in addition to controlling for the endogeneity of court activity, includes time and cross-section fixed effects as well as a set of relevant and quite plausible structural and economic controls. Nevertheless, the magnitude of the link between exogenous changes in courts activity and unemployment may be estimated more precisely in a more elaborated model of the labor market. Future research could explore a number of approaches. For instance, measures of nomination bias could be included in a structural model based more strictly on a theoretical framework linking labor market regulation to the aggregate behavior of labor market participants. Alternatively, measures of nomination bias could be integrated in empirical models explaining, for example, flows into and out of employment at the firm level. 


\section{Conclusions}

The possibility of nomination bias in German labor courts - that is, a preference for nominating judges with political leanings close to the incumbent government - is interesting from at least two perspectives. Normatively, the application of law by judges should be independent from the appointing authority. In addition, from an economic point of view, the presence of nomination bias would give support to the argument that an ideology-driven increase in labor market regulation starting in the 1970s contributed to a decline in the discretion of firms to more flexibly adjust their wage bill and labor force to changing economic environments, with negative consequences for employment.

To better understand how the presence of a nomination bias may interfere with the legal process, we develop a simple model describing the behavior of workers and firms before and during legal action. An important implication of the model is that forward-looking workers and firms will react to the possible presence of nomination bias at the higher court level even at the early stages of the process. For example, before taking a case to a lower-level labor court, both sides will compare the certain payoff of a pre-court settlement with the uncertain expected outcome of a legal dispute that may take them further up the legal path all the way to a higher-level court. If there is nomination bias at the higher court level, any change in its direction would affect the expected payoffs and, thus, their decision to actually file the case. Thus, empirically one should be able to trace an effect of nomination bias in the number of filed claims. By the same token, the impact of a possible nomination bias should be detectable in the number of lower-level court settlements, appeals to lower-level court decisions, and settlements in front of the higher-level court.

Taking these hypotheses to the data, we construct a new panel data set including information on German labor court activity, court characteristics, and the ideological leaning of the state governments nominating higher-level court judges between the early 1970s and 2004. We find, among other things, that court activity is driven by geographical, structural, and economic variables linked to the demand for contract protection by employees, as well as personal and professional characteristics of the judges. In addition, there is strong evidence of nomination bias. More specifically, the political leaning of the appointing state government affects court production at higher-level labor courts with significant repercussions at the lower level of the judiciary along the lines suggested by the theoretical model.

To assess the link between labor courts and unemployment, we provide a simple extension of the empirical model explaining court activity. The 
basic idea is to make use of the measure of nomination bias of higher-level labor courts as an instrument, among others, to control for the endogeneity of court activity with regard to unemployment. The results suggest that an exogenous increase in labor court activity has a positive and economically and statistically significant impact on German unemployment.

The results have potentially important policy implications. From a normative perspective, the evidence pointing to the existence of a nomination bias is worrying. It suggests that the existing appointment process, with its heavy involvement of the executive and legislative branches, does not shield the judiciary from politization - on the contrary. Among the possible solutions would be a more independent nomination process, for instance, based on more intensive peer review or involving independent third parties. Shifting focus to the factor market repercussions of labor court activity, our findings support the view that German courts are an important part of labor market regulation, with negative consequences for the unemployment rate. This suggests that restricting the leeway of labor courts in interpreting and determining existing law - for instance, by imposing more specific legislative guidelines for court decisions aimed at lowering effective employment protection - may have advantages. 


\section{Appendix 1: Model}

What follows is a discussion of the marginal effects of the nomination bias on the various decisions taken by workers and firms at stages 3,2 and 1 .

\section{Decision \#3}

Let us focus on the marginal effect of the nomination bias on the workers' decision to appeal first. We know that the worker will appeal if

$$
\operatorname{Max}\left[E\left[V_{W}^{L A r b G}\right], E\left[T_{W}^{L A r b G}\right]\right]>-U_{W}^{A r b G} .
$$

This means that the worker will appeal if the maximum of the expected values of the two options (settlement or verdict) is larger than the certain payoff from not appealing. For the expected value of a verdict at the higher labor court we can write

$$
\begin{aligned}
E\left[V_{W}^{L A r b G}\right] & =F(\tilde{x}) H_{W}^{L A r b G}-(1-F(\tilde{x})) U_{W}^{L A r b G} \\
& -q_{W}^{L A r b G} c_{W}^{h, L A r b G}-\left(1-q_{W}^{L A r b G}\right) c_{W}^{l, L A r b G} .
\end{aligned}
$$

Clearly, a larger bias of the higher labor court judges towards the interests of the firm decreases the expected value of an appeal for the worker. Consequently, one should observe less workers appealing to the higher labor court.

The expected value of a settlement $E\left[T_{W}^{L A r b G}\right]$ at the higher labor court depends on the threat values for the two parties involved. As we do not have data on settlement values, there is no point in making our model on how settlements are reached more explicit at this point. However, given that the threat values are a function of the nomination bias $\theta$, the worker's settlement value will decrease as the judges are more inclined to the interests of the firm.

In the same way, we can derive the change in appeals by firms as the nomination bias of judges varies. Note, however, that the aggregate effect meaning the sum of the marginal effects for the workers and the firms, which is what we have data for - is ambiguous. But as long as the marginal effects do not cancel out, one is able to trace the effect of a nomination bias on the number of appellations. 


\section{Decision \#2}

Now let us turn to the decision of the worker and the firm on whether to go for a verdict or a settlement at the lower labor court. When the two parties have learned about their costs of pursuing the claim at the lower-level labor court they face the decision of whether to reach a settlement or go for a verdict. They will choose the latter option if the joined surplus from a verdict is higher than the cooperative solution of the game which is zero due to the fact that settlement transfers cancel out, and due to the assumption that transaction costs for reaching a settlement are zero:

$$
\begin{aligned}
& \bar{F}(\tilde{x}) H_{W}^{A r b G}+(1-\bar{F}(\tilde{x})) M a x\left[-U_{W}^{A r b G}, E\left[T_{W}^{L A r b G}\right], E\left[V_{W}^{L A r b G}\right]\right]-c_{W}^{i, A r b G}+ \\
& (1-\bar{F}(\tilde{x})) H_{F}^{A r b G}+\bar{F}(\tilde{x}) M a x\left[-U_{F}^{A r b G}, E\left[T_{F}^{L A r b G}\right], E\left[V_{F}^{L A r b G}\right]\right]-c_{F}^{i, A r b G}>0,
\end{aligned}
$$

with $i=h, l$. The left hand side of eq. (6) consists of the sum of the expected payoffs for the worker and the firm from having a trial net of the trial costs. Should a worker win the trial at the lower level labor court he receives a payoff $H_{W}^{A r b G}$, whereas the firm would have a payoff $H_{F}^{A r b G}$ if it wins. For both sides, the payoffs from a defeat depend on how the case proceeds. First, if the defeated party does not appeal to the higher labor court the payoff for it is $U_{i}^{A r b G}$ with $j=W, F$. Second, an appellation could result in either a settlement or a trial at the higher labor court. It is through the expected value of a settlement $E\left[T_{j}^{L A r b G}\right]$ and the expected value of a trial $E\left[V_{j}^{L A r b G}\right]$ where the nomination bias may enter the calculus of the parties whether to settle the case at stage \#2 or to go for a trial.

\section{Decision \#1}

Finally we look at the decisions of the worker and the firm to file a claim at the lower-level labor court in contrast to reaching a pre-court settlement. Again, the same logic applies. One will observe a trial versus a settlement if the joined surplus of the non-cooperative solution to the game is larger than zero:

$$
\operatorname{Max}\left[E\left[T_{W}^{A r b G}\right], E\left[V_{W}^{A r b G}\right]\right]+\operatorname{Max}\left[E\left[T_{F}^{A r b G}\right], E\left[V_{F}^{A r b G}\right]\right]>0
$$

Not reaching a settlement at the pre-court stage, leaves the two parties with uncertain payoffs. Uncertainty enters, as the parties by assumption do not know the trial costs they would face at the lower labor court. Furthermore, should no pre-court settlement be reached, it is still open whether the case will be settled in front of the lower labor court. Consider the case, in which 
no pre-court settlement is reached. By the time the firm and the worker learn about the costs of a trial, the decision has to be made to whether reach a settlement yielding a payoff $E\left[T_{j}^{A r b G}\right]$ or to go for a trial with a payoff $E\left[V_{j}^{A r b G}\right]$. In any of the two cases, forward looking firms and workers will take into account a nomination bias as was already shown when discussing the trade-offs involved at stage \#2. Thus, even at stage \#1 we should we observe an effect of nomination bias in the recruitment of judges for the higher level labor court. 


\section{Appendix 2: Data Sources}

The following list gives a description of the variables and data sources. Note, that all data used is biannual due to the fact that the data source for our bias variable is only published every other year.

- claims_arbg: Processed claims at lower-level labor courts (by verdict, settlement, or other means) in a state at time $t$. Source: Bundesministerium für Wirtschaft und Arbeit (BMWA)

- settle_arbg: Settlements at a state's lower-level labor courts at time $t$; Source: BMWA

- settle_ratio_arbg: Ratio of settlements over finished claims at lower-level labor courts in a state at time $t$. Source: BMWA

- verdicts_arbg: Verdicts at a state's lower-level labor courts at time $t$; Source: BMWA

- appeals_larbg: Appeals to a state's higher-level labor court at time $t$; Source: BMWA

- appeals_ratio_larbg: Ratio of appeals to a state's higher-level labor court over verdicts at local labor courts in a state at time $t$; Source: BMWA

- settle_larbg: Settlements at a state's higher-level labor court at time $t$; Source: BMWA

- settle_ratio_larbg: Ratio of settlements over appeals to a state's higherlevel labor court at time $t$; Source: BMWA

- bias: The 'Handbuch der Justiz: die Träger und Organe der Rechtsprechenden Gewalt in der Bundesrepublik Deutschland, Deutschen Richterbund (eds.)' (HdJ) is a biannual publication on judges at German courts. It gives information on the judges' names, their age, their entry dates, their sex and whether they carry a higher academic degree. Entry dates of judges at the higher-level labor court were matched with the ideological position of the party in power at the time the judge entered the higher labor court. If the prime minister in the state at the respective time was either a CDU or CSU party member ideology of the respective judge was coded with a 1 otherwise with a 0 . Taking averages over the individual ideological dispositions of judges at a given higher labor court for a year $t$ serves as the bias variable. The states' prime ministers party affiliation can be found at $h t t p: / / w w w . e l e c t i o n . d e$ 
- doc: Denotes for a state and time $t$ the share of higher-level judges holding a doctoral degree; Source: HdJ

- sex: On the individual level a female higher-level judge was coded with 1. Thus, sex varies between 0 and 1 with higher values indicating a larger share of female judges at a state's higher labor court at time $t$; Source: HdJ

- age: Average age of judges at a state's higher labor court at time $t$; Source: HdJ

- area: Is a dummy variable that becomes 1 if the area of a state measure in square kilometers is larger than the mean value; Source: Statistisches Bundesamt (SBA)

- pop: Population (in thousands) in each state at time $t$; Source: SBA

- ur: Unemployment rate, defined as the number of unemployed divided by the labor force in each state at time $t$; Source: SBA

- gdp_real: Is a dummy variable that becomes 1 if the real gross domestic product (GDP) of the state in year $t$ is larger than the mean; Source: Statistisches Landesamt Baden-Württemberg (SLA-BW)

- growth: Growth rate of the real GDP in a state at time $t$; Source: SLA-BW

- industry: Industry share in total GDP, Source: SBA 


\section{Appendix 3: Granger Tests}

Table 7: Granger Causality Tests On Unemployment Rate $(\log (u r))$ And bias

\begin{tabular}{|c|c|c|c|}
\hline Lags & Hypotheses & p-value & number of obs. \\
\hline 1 & $\log ($ ur $)$ does not Granger cause bias & 0.46 & 195 \\
& bias does not Granger cause $\log ($ ur $)$ & 0.37 & \\
\hline 2 & $\log ($ ur $)$ does not Granger cause bias & 0.67 & 178 \\
& bias does not Granger cause $\log ($ ur $)$ & 0.45 & \\
\hline 3 & $\log ($ ur $)$ does not Granger cause bias & 0.29 & 161 \\
& bias does not Granger cause $\log ($ ur $)$ & 0.06 & \\
\hline \multirow{2}{*}{4} & $\log ($ ur $)$ does not Granger cause bias & 0.32 & 144 \\
& bias does not Granger cause $\log ($ ur $)$ & 0.13 & \\
\hline 5 & $\log ($ ur $)$ does not Granger cause bias & 0.28 & 127 \\
& bias does not Granger cause $\log ($ ur $)$ & 0.13 & \\
\hline
\end{tabular}




\section{References}

Autor, D. (2003): "Outsourcing at will: the contribution of unjust dismissal doctrine to the growth of employment outsourcing," Journal of Labor Economics, 21, 1-42.

Autor, D., J. D. III, And S. Schwab (2004a): "The costs of wrongful discharge laws," Typescript, MIT.

- (2004b): "The employment consequences of wrongful-discharge laws: large, small, or none at all?" Typescript, MIT, forthcoming American Economic Review Papers and Proceedings.

Berger, H. (1998): "Regulation in Germany: some stylized facts about its time path, causes, and consequences," Zeitschrift für Wirtschafts- und Sozialwissenschaften, 118, 185-220.

Berger, H. And S. DAnninger (2006): "Does excessive regulation impede growth in Germany?" IMF Country Report 06/17, 106-133.

Bertola, G., T. Boeri, and S. Cazes (1999): "Employment protection and labor market adjustment in OECD countries: evolving institutions and variable enforcement," ILO, Employment and Training Papers, No. 48, Geneva.

Blanchard, O. and J. Tirole (2003): "Contours of employment protection reform," MIT Working Paper 03-35, November 2003.

Cooter, R. And D. Rubinfeld (1989): "Economic analysis of legal disputes and their resolution," Journal of Economic Literature, 27, 10671097.

Daughety, A. F. (2000): "Settlement," in Encyclopedia of Law and Economics, ed. by B. Bouckaert and G. D. Geest, Edward Elgar, 95-158.

Franz, W. (1994): "Chancen und Risiken einer Flexibilisierung des Arbeitsrechts aus ökonomischer Sicht," Zeitschrift für Arbeitsrecht, 25, 439-462.

Frick, B. AND M. SchneIder (1999): "Zunehmende Konfliktregulierung durch Arbeitsgerichte? Eine ökonomische Analyse der Häufigkeit von Kündigungsschutzprozessen," in Entlohnung und Arbeitszeitgestaltung im Rahmen betrieblicher Personalpolitik, ed. by U. Backes-Gellner, M. Kräkel, and C. Grund, Hampp, 157-183. 
Goerke, L. And M. Pannenberg (2005): "Severance pay and shadow of the law: evidence for West Germany," CESifo Working Paper 1619.

Hanssen, F. A. (2004): "Is there a politically optimal level of judicial independence?" American Economic Review, 94, 712-729.

Ichino, A., M. Polo, And E. Rettore (2003): "Are judges biased by labor market conditions?" European Economic Review, 47, 913-944.

LEvy, G. (2005): "Careerist judges and the appeals process," RAND Journal of Economics, 36, 275-297.

OECD (2004a): Economic survey 2004 Germany. - (2004b): Economic Outlook.

Richardi, R. And O. Wlotzke (1992): Münchner Handbuch zum Arbeitsrecht, (eds.), vol. Band 1, Beck.

SACHVERSTÄNDIGENRAT (2003): Jahresgutachten 2003/04.

SchneIDer, M. (2002): "Auf der Suche nach dem 'inoffiziellen Richterrecht': Konfliktbeteiligung und Rechtschöpfung durch die Landesarbeitsgerichte," Beiträge zur Arbeitsmarkt- und Berufsforschung, BeitrAB 259, 173-190.

SCHNEIDER, M. R. (2005): "Judicial career incentives and court performance: an empirical study of the German labour courts of appeal," European Journal of Law and Economics, 20, 127-144.

Soltwedel, R. (1983): "Employment problems in West Germany - the role of institutions, labor law, and government intervention," CarnegieRochester Series on Public Policy, 28, 153-220.

Teubner, E. (1984): Die Bestellung zum Berufsrichter in Bund und Ländern: Entwicklung, Modelle und Analysen, Heymann.

YounG, D. (2003): "Employment protection legislation: its economic impact and the case for reform," European Economy, 186. 


\section{CESifo Working Paper Series}

(for full list see www.cesifo-group.de)

1689 Gebhard Kirchgaessner and Silika Prohl, Sustainability of Swiss Fiscal Policy, March 2006

1690 A. Lans Bovenberg and Peter Birch Sørensen, Optimal Taxation and Social Insurance in a Lifetime Perspective, March 2006

1691 Moritz Schularick and Thomas M. Steger, Does Financial Integration Spur Economic Growth? New Evidence from the First Era of Financial Globalization, March 2006

1692 Burkhard Heer and Alfred Maussner, Business Cycle Dynamics of a New Keynesian Overlapping Generations Model with Progressive Income Taxation, March 2006

1693 Jarko Fidrmuc and Iikka Korhonen, Meta-Analysis of the Business Cycle Correlation between the Euro Area and the CEECs, March 2006

1694 Steffen Henzel and Timo Wollmershaeuser, The New Keynesian Phillips Curve and the Role of Expectations: Evidence from the Ifo World Economic Survey, March 2006

1695 Yin-Wong Cheung, An Empirical Model of Daily Highs and Lows, March 2006

1696 Scott Alan Carson, African-American and White Living Standards in the $19^{\text {th }}$ Century American South: A Biological Comparison, March 2006

1697 Helge Berger, Optimal Central Bank Design: Benchmarks for the ECB, March 2006

1698 Vjollca Sadiraj, Jan Tuinstra and Frans van Winden, On the Size of the Winning Set in the Presence of Interest Groups, April 2006

1699 Martin Gassebner, Michael Lamla and Jan-Egbert Sturm, Economic, Demographic and Political Determinants of Pollution Reassessed: A Sensitivity Analysis, April 2006

1700 Louis N. Christofides and Amy Chen Peng, Major Provisions of Labour Contracts and their Theoretical Coherence, April 2006

1701 Christian Groth, Karl-Josef Koch and Thomas M. Steger, Rethinking the Concept of Long-Run Economic Growth, April 2006

1702 Dirk Schindler and Guttorm Schjelderup, Company Tax Reform in Europe and its Effect on Collusive Behavior, April 2006

1703 Françoise Forges and Enrico Minelli, Afriat's Theorem for General Budget Sets, April 2006 
1704 M. Hashem Pesaran, Ron P. Smith, Takashi Yamagata and Liudmyla Hvozdyk, Pairwise Tests of Purchasing Power Parity Using Aggregate and Disaggregate Price Measures, April 2006

1705 Piero Gottardi and Felix Kubler, Social Security and Risk Sharing, April 2006

1706 Giacomo Corneo and Christina M. Fong, What's the Monetary Value of Distributive Justice?, April 2006

1707 Andreas Knabe, Ronnie Schoeb and Joachim Weimann, Marginal Employment Subsidization: A New Concept and a Reappraisal, April 2006

1708 Hans-Werner Sinn, The Pathological Export Boom and the Bazaar Effect - How to Solve the German Puzzle, April 2006

1709 Helge Berger and Stephan Danninger, The Employment Effects of Labor and Product Markets Deregulation and their Implications for Structural Reform, May 2006

1710 Michael Ehrmann and Marcel Fratzscher, Global Financial Transmission of Monetary Policy Shocks, May 2006

1711 Carsten Eckel and Hartmut Egger, Wage Bargaining and Multinational Firms in General Equilibrium, May 2006

1712 Mathias Hoffmann, Proprietary Income, Entrepreneurial Risk, and the Predictability of U.S. Stock Returns, May 2006

1713 Marc-Andreas Muendler and Sascha O. Becker, Margins of Multinational Labor Substitution, May 2006

1714 Surajeet Chakravarty and W. Bentley MacLeod, Construction Contracts (or "How to Get the Right Building at the Right Price?”), May 2006

1715 David Encaoua and Yassine Lefouili, Choosing Intellectual Protection: Imitation, Patent Strength and Licensing, May 2006

1716 Chris van Klaveren, Bernard van Praag and Henriette Maassen van den Brink, Empirical Estimation Results of a Collective Household Time Allocation Model, May 2006

1717 Paul De Grauwe and Agnieszka Markiewicz, Learning to Forecast the Exchange Rate: Two Competing Approaches, May 2006

1718 Sijbren Cnossen, Tobacco Taxation in the European Union, May 2006

1719 Marcel Gérard and Fernando Ruiz, Interjurisdictional Competition for Higher Education and Firms, May 2006

1720 Ronald McKinnon and Gunther Schnabl, China's Exchange Rate and International Adjustment in Wages, Prices, and Interest Rates: Japan Déjà Vu?, May 2006 
1721 Paolo M. Panteghini, The Capital Structure of Multinational Companies under Tax Competition, May 2006

1722 Johannes Becker, Clemens Fuest and Thomas Hemmelgarn, Corporate Tax Reform and Foreign Direct Investment in Germany - Evidence from Firm-Level Data, May 2006

1723 Christian Kleiber, Martin Sexauer and Klaus Waelde, Bequests, Taxation and the Distribution of Wealth in a General Equilibrium Model, May 2006

1724 Axel Dreher and Jan-Egbert Sturm, Do IMF and World Bank Influence Voting in the UN General Assembly?, May 2006

1725 Swapan K. Bhattacharya and Biswa N. Bhattacharyay, Prospects of Regional Cooperation in Trade, Investment and Finance in Asia: An Empirical Analysis on BIMSTEC Countries and Japan, May 2006

1726 Philippe Choné and Laurent Linnemer, Assessing Horizontal Mergers under Uncertain Efficiency Gains, May 2006

1727 Daniel Houser and Thomas Stratmann, Selling Favors in the Lab: Experiments on Campaign Finance Reform, May 2006

1728 E. Maarten Bosker, Steven Brakman, Harry Garretsen and Marc Schramm, A Century of Shocks: The Evolution of the German City Size Distribution 1925 - 1999, May 2006

1729 Clive Bell and Hans Gersbach, Growth and Enduring Epidemic Diseases, May 2006

1730 W. Bentley MacLeod, Reputations, Relationships and the Enforcement of Incomplete Contracts, May 2006

1731 Jan K. Brueckner and Ricardo Flores-Fillol, Airline Schedule Competition: ProductQuality Choice in a Duopoly Model, May 2006

1732 Kerstin Bernoth and Guntram B. Wolff, Fool the Markets? Creative Accounting, Fiscal Transparency and Sovereign Risk Premia, May 2006

1733 Emmanuelle Auriol and Pierre M. Picard, Government Outsourcing: Public Contracting with Private Monopoly, May 2006

1734 Guglielmo Maria Caporale and Luis A. Gil-Alana, Modelling Structural Breaks in the US, UK and Japanese Unemployment Rates, May 2006

1735 Emily J. Blanchard, Reevaluating the Role of Trade Agreements: Does Investment Globalization Make the WTO Obsolete?, May 2006

1736 Per Engström and Bertil Holmlund, Tax Evasion and Self-Employment in a High-Tax Country: Evidence from Sweden, May 2006

1737 Erkki Koskela and Mikko Puhakka, Cycles and Indeterminacy in Overlapping Generations Economies with Stone-Geary Preferences, May 2006 
1738 Saku Aura and Thomas Davidoff, Supply Constraints and Housing Prices, May 2006

1739 Balázs Égert and Ronald MacDonald, Monetary Transmission Mechanism in Transition Economies: Surveying the Surveyable, June 2006

1740 Ben J. Heijdra and Ward E. Romp, Ageing and Growth in the Small Open Economy, June 2006

1741 Robert Fenge and Volker Meier, Subsidies for Wages and Infrastructure: How to Restrain Undesired Immigration, June 2006

1742 Robert S. Chirinko and Debdulal Mallick, The Elasticity of Derived Demand, Factor Substitution and Product Demand: Corrections to Hicks' Formula and Marshall's Four Rules, June 2006

1743 Harry P. Bowen, Haris Munandar and Jean-Marie Viaene, Evidence and Implications of Zipf's Law for Integrated Economies, June 2006

1744 Markku Lanne and Helmut Luetkepohl, Identifying Monetary Policy Shocks via Changes in Volatility, June 2006

1745 Timo Trimborn, Karl-Josef Koch and Thomas M. Steger, Multi-Dimensional Transitional Dynamics: A Simple Numberical Procedure, June 2006

1746 Vivek H. Dehejia and Yiagadeesen Samy, Labor Standards and Economic Integration in the European Union: An Empirical Analysis, June 2006

1747 Carlo Altavilla and Paul De Grauwe, Forecasting and Combining Competing Models of Exchange Rate Determination, June 2006

1748 Olaf Posch and Klaus Waelde, Natural Volatility, Welfare and Taxation, June 2006

1749 Christian Holzner, Volker Meier and Martin Werding, Workfare, Monitoring, and Efficiency Wages, June 2006

1750 Steven Brakman, Harry Garretsen and Charles van Marrewijk, Agglomeration and Aid, June 2006

1751 Robert Fenge and Jakob von Weizsäcker, Mixing Bismarck and Child Pension Systems: An Optimum Taxation Approach, June 2006

1752 Helge Berger and Michael Neugart, Labor Courts, Nomination Bias, and Unemployment in Germany, June 2006 